\title{
Analysis of Carl Joachim Andersen Op.15 Flute Etudes Used in Flute Education
}

\author{
Gülten Cüceoğlu Önder ${ }^{1}$ \\ ${ }^{1}$ Department of Music Teacher Education, Education Faculty, Burdur Mehmet Akif Ersoy University, Burdur, \\ Turkey \\ Correspondence: Gülten Cüceoğlu Önder, Department of Music Teacher Education, Education Faculty, Burdur \\ Mehmet Akif Ersoy University, Burdur, Turkey. E-mail: gultenka@gmail.com
}

Received: December 27, 2020

Accepted: February 5, $2021 \quad$ Online Published: March 24, 2021

doi:10.5539/ies.v14n4p57

URL: https://doi.org/10.5539/ies.v14n4p57

\begin{abstract}
In this study, it was aimed to examine C. J. Andersen's op.15 etude book used in flute education in terms of measurement units, vocalization techniques, technical studies, nuance terms, speed terms, tonality. Thus it is aimed to reveal the gains that the etudes can provide for the student. Document analysis method was used in the study. The summary of results as follows. Etudes are mostly written in 4/4 unit of measure. It was found that mostly legato and staccato was used a great extent in the etudes. Interval was run the most in the etudes. Also etudes include technical studies such as arpeggio, chromatic scale, scale studies, and tonality. The terms crescendo and decrescendo nuances were used in all of the etudes. Mezzoforte, forte and piano nuances were also included in the etudes. Allegro and its varieties have been used as the term of speed in most of the etudes. In the etudes, 24 different tones were used, 12 of them in major tones and 12 of them in minor tones. Tone, measure and tempo changes were made in some etudes. Considering the results, Andersen's op. 15 etude book systematically covers many issues in terms of flute education. Etudes can provide to the student in flute education both in technical and musical gains; legato, tongue technique, articulation, interval, arpeggio, intonation, chromatic scale, phrasing, good breathing technique, a quality tone and a correct blowing angle. Instead of playing a etude book from the beginning to the end, the student's difficulties can be eliminated by conducting etudes on whatever subject he/she has inadequate or difficulty. With this analysis, the topics in the etudes can be classified and presented in line with the needs of the students.
\end{abstract}

Keywords: flute education, C. J. Andersen, etude, analysis

\section{Introduction}

Carl Joachim Andersen was born on April 29, 1847 in Copenhagen, Denmark. He is one of the most recognized Danish flutists, one of the most talented musicians of his time, and an important leader of Danish cultural and musical life. A flutist, conductor, composer and instructor, Andersen received his flute education from his professional flutist father, Christian Joachim Andersen, and gave his first concert as a soloist in Copenhagen when he was 13. He started his professional career as the first flute in the orchestra under Niels Gade. He was one of the founders of the Berlin Philharmonic Orchestra in 1881, served as the head flutist in this orchestra for 10 years and was the assistant conductor of the orchestra. He suffered tongue paralysis in 1892 and had to end his career as a lead flutist at the Berlin Philharmonic. Returning to Copenhagen, he continued his career as composer and conducting, completing many of his compositions and etude collections. He opened an Orchestra School in 1896 and aimed to train young musicians in collective music making with this school. He trained many flutists in his school that he managed for 13 years. In 1905, Andersen was knighted and appointed as a professor. He died in Copenhagen on 7 May 1909 (Dzapo, 1996; Fonville, 1981).

One of the prominent names of flute literature and also a flute artist, C. J. Andersen made a great contribution to the flute repertoire with his numerous piano, orchestral accompaniment works and etudes he composed. Andersen is known as the "Chopin of Flute". The etude books written by Andersen were published in 1892. These were widely used in music schools in Berlin, Leipzig, Dresden, Hamburg, Vienna, Weimar, St. Petersburg, Moscow, Paris (Dzapo, 1996). Etude books are among the most basic resources and are widely used today. Andersen's flute etudes Op. 15, op.21, op.30, op.33, op.37, op.41, op.60/I-II, op.63/I-II. He dedicated the book Op.15 to his father and his first flute teacher, Christian Joachim Andersen. 
Carl Joachim Andersen's eight etude books (totally 188 etudes) have served worldwide pedagogically since the late 19th century and cover a wide range of flute literature (Dzapo, 2007; Fonville, 1981). His etudes, which are widely used in today's flute education, deal with many technical and musical issues. It is possible to list the etudes from easy to difficult as follows; Op.41, op.37, op.33, op.21, op.30, op.15, op.63, op.60 (Fonville, 1981). Therefore, we can say that op. 15 etude book is one of the difficult studies in terms of level.

The first etude book written by Andersen is op.15. Some of the early works, for example the Impromptu. Op. 7, and AuBord de la Mer, Op. 9, are among his most imaginative. "These pieces, written in the midst of his rise to fame in Berlin, are masterful compositions that have been an important part of the flute player's. An etude, by its very nature, usually focuses on a technical challenge and therefore tends to be repetitive. What is striking about Opus 15, however, is that Andersen, while limiting the number of compositional resources he manipulates in each etude, creates really interesting music" (Dzapo, 2007, p. 26).

Etude is a special composition created to ensure the technical development of the performer on his instrument (Scholes, 1992; Sadie, 1995). "Etudes are practical pieces used to improve our various knowledge and skills on style, phrasing, technique, tone, intonation, and harmony" (Lancaster, 1994, p. 16). "Each etude plays an important role in overcoming many difficulties that a student/performer may encounter in the works he/she has included in their repertoire, with one or more technical and musical goals. Being an indispensable element of instrument training, etudes are among the indispensable elements of flute education and repertoire as in almost every instrument" (Cüceoğlu \& Berki, 2007, p. 227).

Many technical and musical subjects can be studied together in the etudes, which have an important role in gaining control over the instrument and in the development of technical and musical skills. In flute education, many technical subjects are taught and various etudes are used to enable the student to apply these techniques in the most accurate way. When the flute literature is examined, it is seen that there are many etude books to overcome technical and musical difficulties. However, in these etude books, it is mostly not mentioned which study is written for what purpose. Instead of playing an etude book from beginning to end, it will be more useful to run etudes on what the student has difficulties (Önder\& Yıldız 2017). If it is determined in advance what the subjects dealt with in the etudes are determined, etudes can be conducted in line with the deficiencies of the student and these deficiencies or difficulties can be eliminated. Thus, the gains expected from the etudes can be realized more efficiently and in a shorter time. From this point of view, it is thought that there is a need for a research examining the op. 15 flute etudes, which is the first study book of C. J. Andersen, which has an important place in the flute literature.

\subsection{Purpose of the Study}

With this study, it was aimed to examine the etudes in C. J. Andersen's op.15 etude book in terms of unit of measure, vocalization techniques, technical studies, nuance terms, speed terms, tone, and thus to reveal the gains that the etudes can provide for the student.

For this purpose, answers of the following questions were sought:

1- Which measure units used in the etudes?

2- Which vocalization techniques used in the etudes?

3- Whichtechnical studies used in the etudes?

4- Whichnuance terms used in the etudes?

5 - Whichspeed terms used in the etudes?

6- Whichtones used in the etudes?

\subsection{The Importance of Research}

C. J. Andersen's op. 15 etude book is one of the etude books that can be considered difficult in terms of level that deals with technical and musical issues. Each of the 24 etudes is systematically constructed etudes focusing on very different technical and musical topics. By analyzing the Op.15 etudes book, it will be possible to find out which subjects are included in the etudes, and to run etudes for what the student has difficulties. Thus, the etudes will contribute to the field by being a resource for flute educators and students.

\section{Method}

In the study, C. J. Andersen's edition of op.15 24 Grosse Etuden für Flöte (Hamburg, Max Leichssenring) was used. Because there are different editions of op. 15 etude book. In the study, all 24 etudes were examined using the document analysis method. "Document review covers the analysis of written materials containing 
information about the phenomenon or phenomena aimed to be researched" (Yıldırım \& Şimşek, 2006, p. 187). In the field of education, textbooks, program instructions, student and teacher handbooks, student course assignments, lesson units and plans, magazines and books can also be subject to document analysis (Yildirım \& Şimşek, 2006, p. 188). In line with the research questions determined in the study, the data were obtained by analyzing the etudes in detail. The data were arranged by taking expert opinions and presented in tables.

\section{Results}

In this section, the study findings are presented in line with research questions.

Table 1. Distribution of measurement units used in the etudes

\begin{tabular}{llll}
\hline Measurement units & Etude Numbers & Change in unit of measure & Frequency \\
\hline $2 / 4$ & $9 \mathrm{a}, 9 \mathrm{~b}, 15,17,21$ & 5 \\
\hline $3 / 4$ & $1,6,8,11,16$ & 5 \\
\hline $4 / 4$ & $2,4 \mathrm{a}, 4 \mathrm{~b}, 5,13,20,22,23,24$ & \\
\hline $3 / 8$ & $3,12,18$ & 3 \\
\hline $6 / 8$ & 14,19 & & 2 \\
\hline $12 / 8$ & 7,10 & & 2 \\
\hline Cebare & 24 & & 1 \\
\hline
\end{tabular}

When Table 1 is examined, it is seen that 9 etudes were written with $4 / 4$ measures and 5 etudes were written with $2 / 4$ and $3 / 4$ measures. This is followed by $3 / 8,6 / 8,12 / 8$ and cebare. Two different measurement units were used in etudes number 24. At the beginning, cebare started in the 17 th measure became $4 / 4$, in the 64th measure became cebare and again in the 114th measure the etudes was completed by turning to the $4 / 4$ measurement unit.

Table 2. Distribution of the vocalization techniques used in the etudes

\begin{tabular}{lcc}
\hline Vocalization Techniques & Etude Numbers & Frequency \\
\hline Legato & $1,2,3,5,6,7,8,10,11,12,13$, & 16 \\
& $14,19,21,23,24$ & 10 \\
\hline Staccato & $2,4 \mathrm{a}, 6,8,9 \mathrm{a}, 9 \mathrm{~b}, 12,18,20,24$ & 10 \\
\hline 2 legato & $14,15,17,23$ & 4 \\
\hline 2 legato -2 tongued & $2,4 \mathrm{~b}, 22$ & 3 \\
\hline 2 legato -3 tongued & 16 & 1 \\
\hline
\end{tabular}

According to Table 2, the most used vocalization technique is legato. Staccato technique has been widely used in etudes. In addition, there are 2 legato, 2 legato- 2 tongued and 2 legato- 3 tongued etudes.

The vocalization techniques used in the etudes have been studied using various legato and tongued applications. Detailed tables regarding legato and tongued applications are presented below.

Table 3. Distribution of legato applications used in the etudes

\begin{tabular}{|c|c|c|}
\hline Legato Applications & Etude Numbers & Frequency \\
\hline & $1,2,13,5,11,24$ & 6 \\
\hline & $1,2,5,11,13$ & 5 \\
\hline & $1,5,11,13,24$ & 5 \\
\hline
\end{tabular}




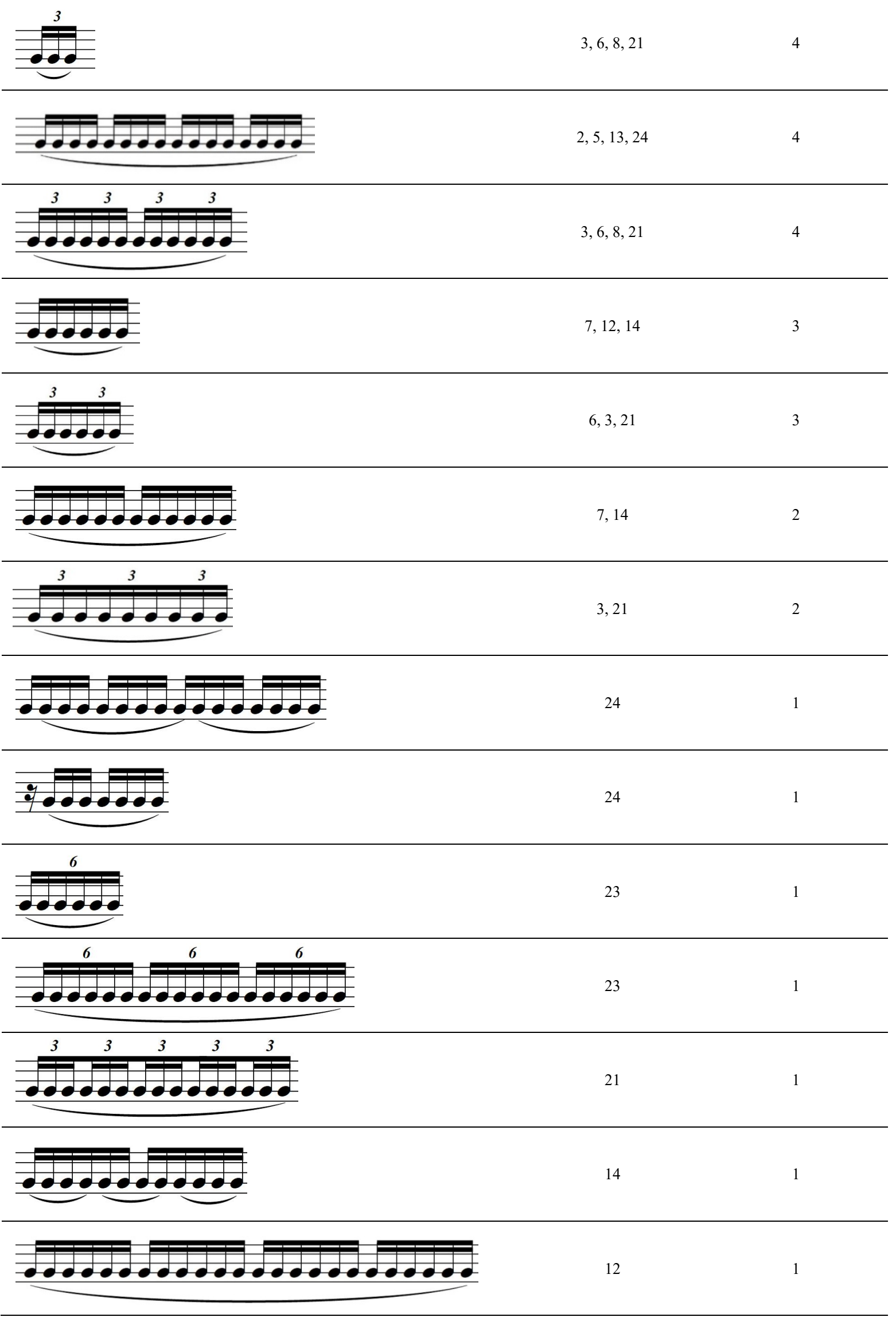




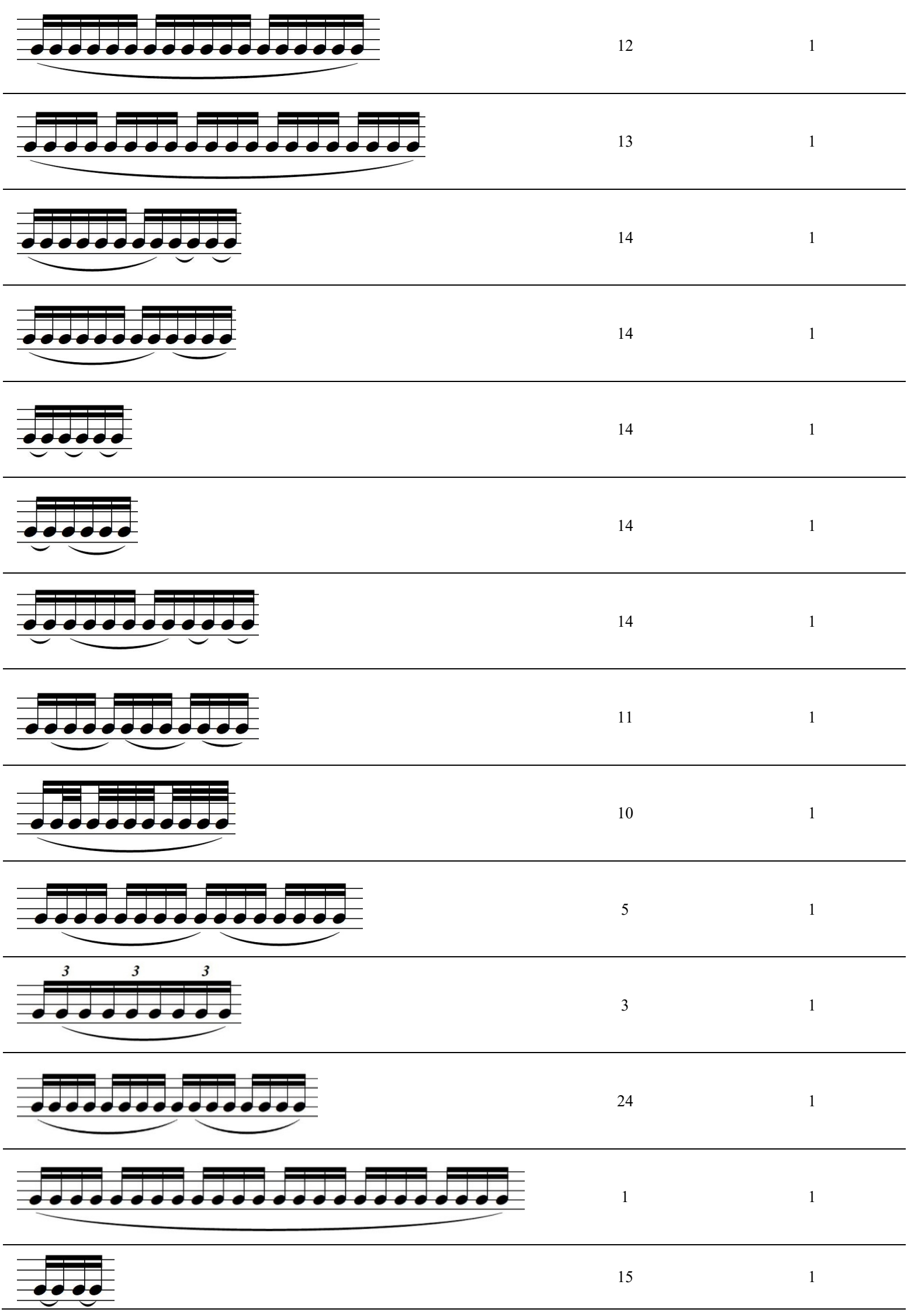

As seen in Table 3, the legato application was included in 31 different waysin the etudes. According to the table, 
legato mostly used in this rhythm patterns;
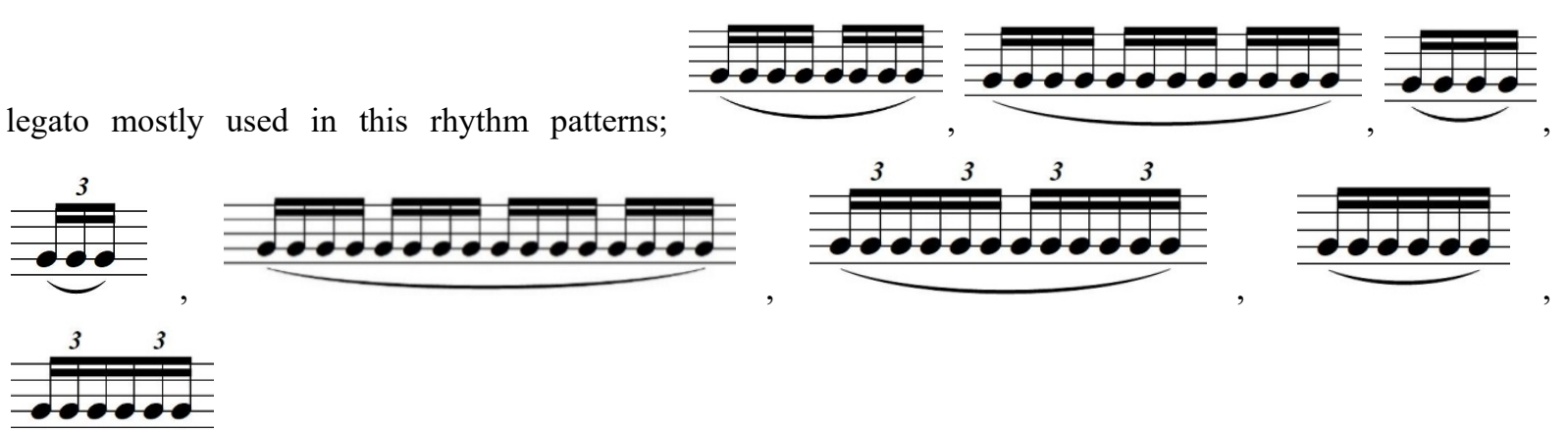

. In addition to these, it is seen that many different legato applications are included in the etudes.

Table 4. Distribution of staccato applications used in the etudes

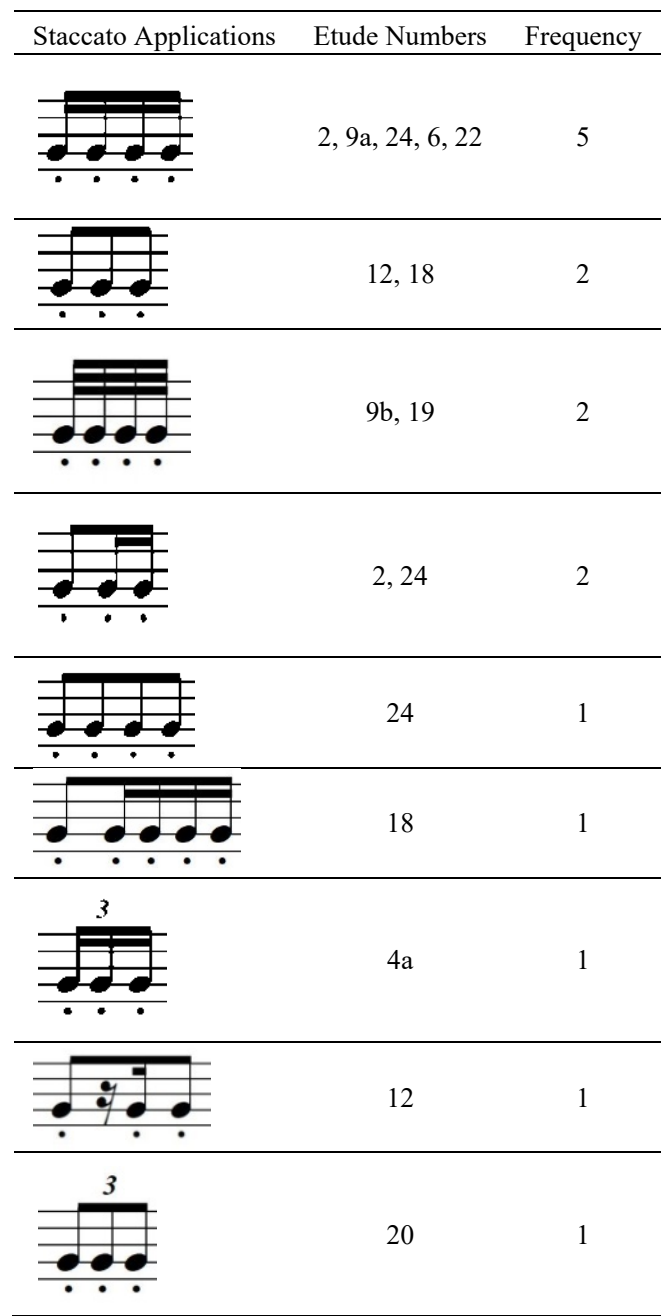

Looking at Table 4, it is seen that staccato applications are included in 9 different ways in the etudes. In etudes

used staccato, it is seen that

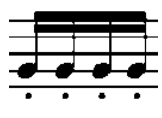

rhythm patterns are applied at most. This is followed by
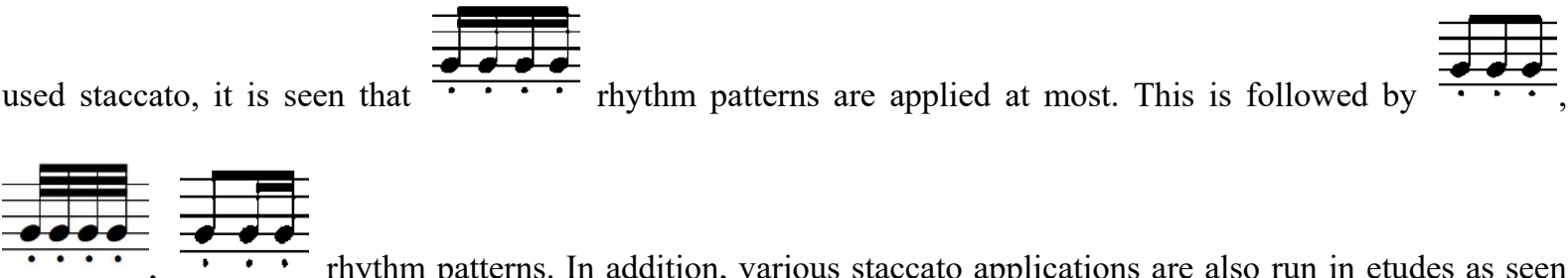

rhythm patterns. In addition, various staccato applications are also run in etudes as seen 
in table.

Table 5. Distribution of legato and tongued applications used in the etudes

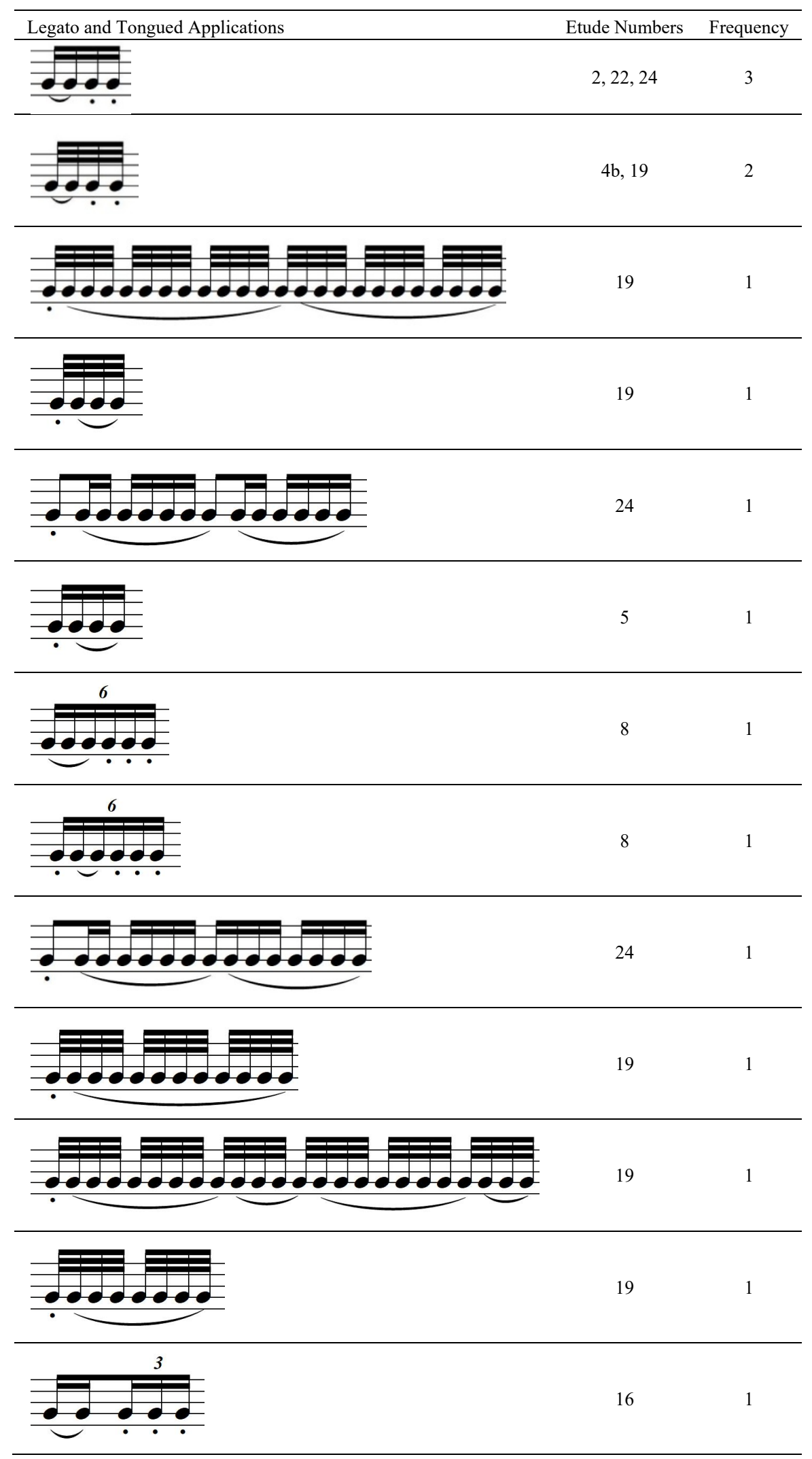




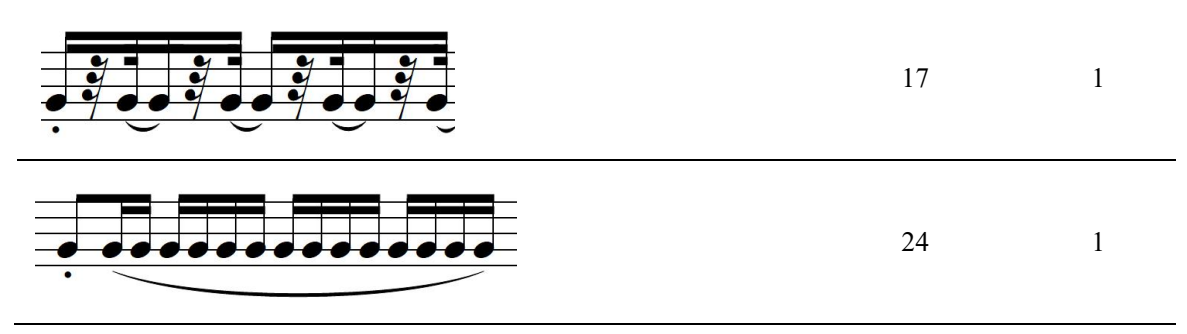

As seen in Table 5, etudes have included 15 different ways of legato and tongued applications. In etudes that deal

with the legato-tongued playing technique together mostly used by

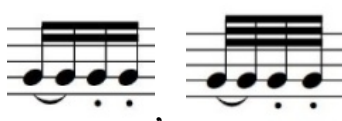

rhythm patterns. It is seen in the table that other legato-tongued applications used in etudes are in a very rich variety and difficult applications.

Table 6. Distribution of ornaments practices used in the etudes

\begin{tabular}{|c|c|c|}
\hline Ornaments & Etude Numbers & Frequency \\
\hline $\begin{array}{l}n \\
00 \\
0\end{array}$ & 6 & 1 \\
\hline & 6 & 1 \\
\hline & 6 & 1 \\
\hline & 6 & 1 \\
\hline & 6 & 1 \\
\hline$\stackrel{\sim}{\rightleftharpoons 0}$ & 6 & 1 \\
\hline & 6 & 1 \\
\hline & 6 & 1 \\
\hline 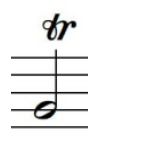 & 6 & 1 \\
\hline
\end{tabular}




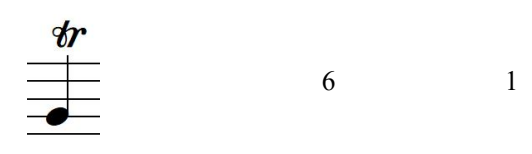

Looking at Table 6, it is seen that ornament signs are used in 10 different ways in only one etude (6th etude). Applications regarding trill, mordan, grace note, gruppetto are shown in the table.

Table 7. Distribution of technical studies used in the etudes

\begin{tabular}{lcc}
\hline Technical Studies & Etude Numbers & Frequency \\
\hline Interval & $2,3,4 \mathrm{a}, 4 \mathrm{~b}, 5,6,7,9 \mathrm{a}, 9 \mathrm{~b}, 10,11,12,14,15,16,17,18,19,20,22,23,24$ & 22 \\
\hline Chromatic scale & $2,3,6,13,18,21$ & 6 \\
\hline Scale studies & $2,5,8,9 \mathrm{a}, 9 \mathrm{~b}, 10$ & 6 \\
\hline Arpeggio & $1,3,5,6,8,9 \mathrm{a}, 9 \mathrm{~b}, 11,14,16,19,23,24$ & 13 \\
\hline Triole Pattern & $3,4 \mathrm{a}, 8,16,20,21$ & 6 \\
\hline Different Ritm Pattern & 12,17 & 2 \\
\hline Ornament & 6 & 1 \\
\hline Tonality & $6,11,14,18,24$ & 5 \\
\hline
\end{tabular}

When Table 7 is examined, it is seen that mostly interval and arpeggio studies are included. In addition, chromatic series, scale studies, triole studies, tonality studies are also included. It is seen that ornament works used in the only 6th etude.

Table 8. Distribution of nuance terms used in the etudes

\begin{tabular}{|c|c|c|c|c|c|c|c|}
\hline Etudes No & Mf & $\mathrm{f}$ & $\mathrm{ff}$ & $\mathrm{p}$ & $\mathrm{pp}$ & Crescendo & Decrescendo \\
\hline 1 & + & + & - & + & - & + & + \\
\hline 2 & + & + & - & + & - & + & + \\
\hline 3 & + & + & - & + & + & + & + \\
\hline $4 \mathrm{a}$ & + & + & - & + & + & + & + \\
\hline $4 \mathrm{~b}$ & + & + & - & + & - & + & + \\
\hline 5 & - & + & - & - & - & + & + \\
\hline 6 & + & + & - & + & - & + & + \\
\hline 7 & + & + & - & + & + & + & + \\
\hline 8 & + & + & - & + & + & + & + \\
\hline $9 \mathrm{a}$ & + & + & - & + & - & + & + \\
\hline $9 \mathrm{~b}$ & + & + & - & + & - & + & + \\
\hline 10 & - & - & - & + & + & + & + \\
\hline 11 & + & + & - & + & - & + & + \\
\hline 12 & + & + & + & + & - & + & + \\
\hline 13 & - & + & - & + & - & + & + \\
\hline 14 & + & + & - & + & + & + & + \\
\hline 15 & + & + & + & + & - & + & + \\
\hline 16 & + & + & - & + & + & + & + \\
\hline 17 & + & + & - & - & + & + & + \\
\hline 18 & + & + & + & + & + & + & + \\
\hline 19 & + & + & + & + & + & + & + \\
\hline 20 & + & + & - & + & + & + & + \\
\hline 21 & + & + & + & + & + & + & + \\
\hline 22 & - & + & + & + & - & + & + \\
\hline 23 & + & + & + & + & + & + & + \\
\hline 24 & + & + & + & + & - & + & + \\
\hline Frequency & 22 & 25 & 8 & 24 & 13 & 26 & 26 \\
\hline
\end{tabular}


When Table 8 is examined, it is seen that crescendo and decrescendo were used in all etudes. Forte, mezzoforte, and piano were used in most of the etudes.

Table 9. Distribution of speed terms and metronome values used in the etudes

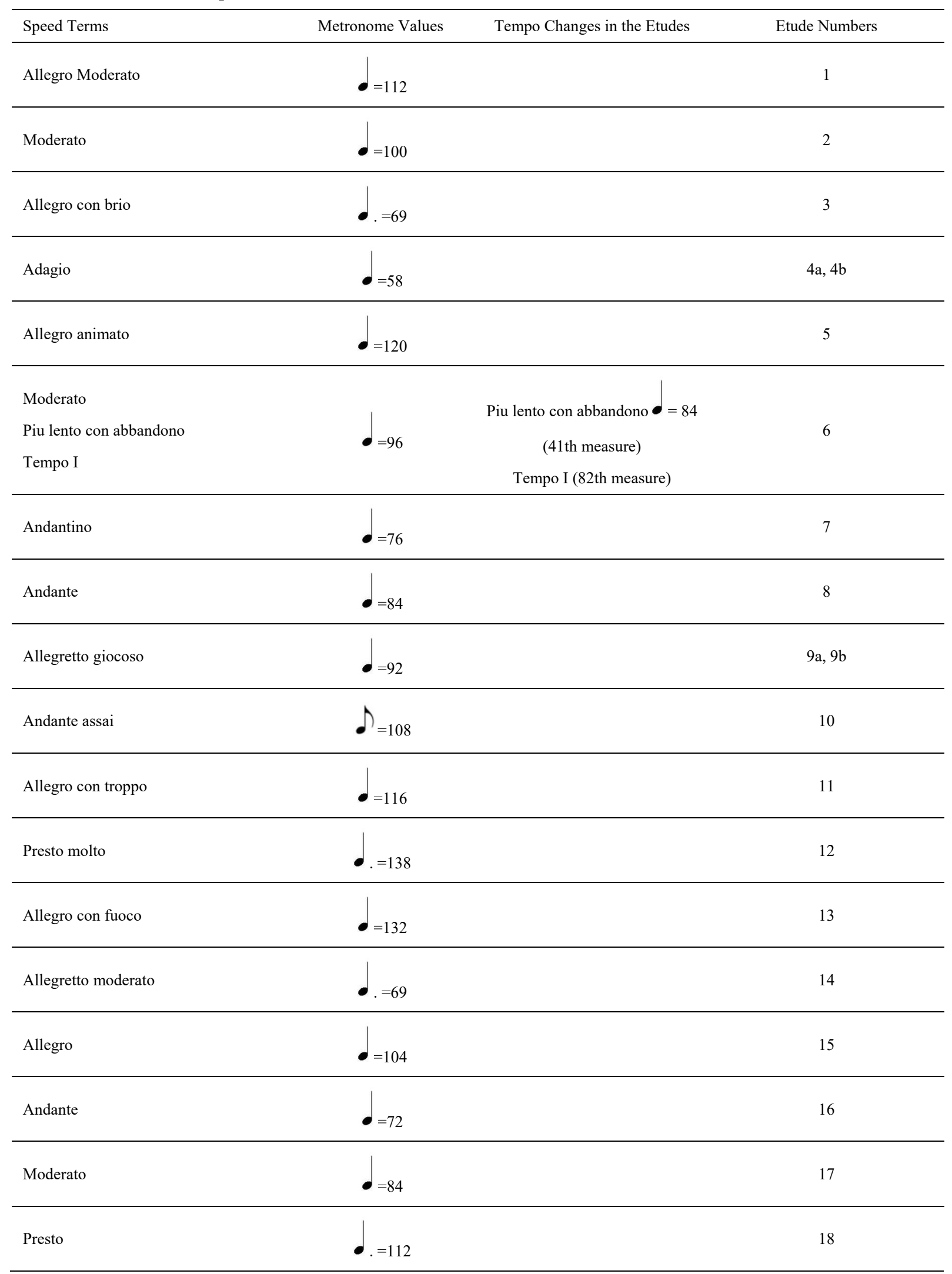




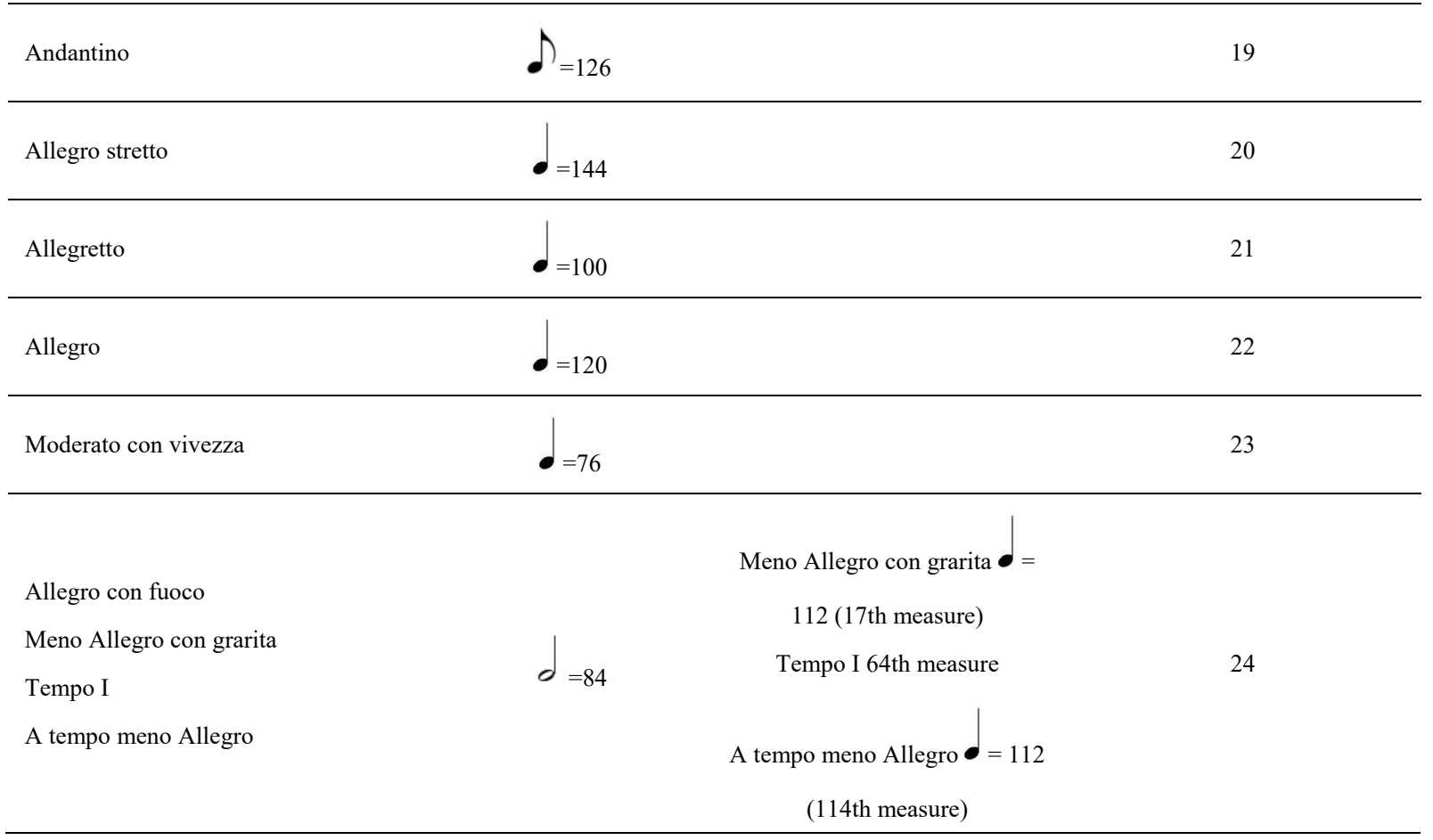

In Table 9, each etude was examined and the data were presented in terms of metronome values and speed terms. As can be seen from the table, most of the 24 etudes were written in different metronome values and again different speed terms were used. Looking at the metronome values, it is seen that the lowest value is $\bullet=58$ and the highest value is $\downarrow=144$. However, metronome values mostly refer to tempo that requires fast playing. When the terms of speed are examined, it is understood that most of the etudes are in the form of allegro and its varieties, but speed terms such as adagio, andante, presto are also included. In the 6th and 24th studies, it is seen that there are changes in both speed terms and metronome values. The data on the speed terms are analyzed and interpreted in more detail in table 10 .

Table 10. Distribution of speed terms used in the etudes

\begin{tabular}{lcc}
\hline Speed terms & Etude Numbers & Frequency \\
\hline Adagio & $4 \mathrm{a}, 4 \mathrm{~b}$ & 2 \\
\hline Andante & 8,16 & 2 \\
\hline Andante assai & 10 & 1 \\
\hline Andantino & 7,19 & 2 \\
\hline Moderato & $2,6,17,23$ & 4 \\
\hline Allegro & 15,22 & 2 \\
\hline Allegro Moderato & 1 & 1 \\
\hline Allegro con brio & 3 & 1 \\
\hline Allegro animato & 5 & 1 \\
\hline Allegretto giocoso & $9 \mathrm{a}, 9 \mathrm{~b}$ & 2 \\
\hline Allegro con troppo & 11 & 1 \\
\hline Allegro con fuoco & 13,24 & 2 \\
\hline Allegretto moderato & 14 & 1 \\
\hline Allegro stretto & 20 & 1 \\
\hline Allegretto & 21 & 1 \\
\hline
\end{tabular}




\begin{tabular}{lcl}
\hline Allegro con grarita & 24 & 1 \\
\hline Presto & 18 & 1 \\
\hline Presto molto & 12 & 1 \\
\hline Piu lento con abbandono & 6 & 1 \\
\hline
\end{tabular}

Looking at Table 10, it is understood that 19 speed terms are used in total. Of these 19 speed terms, moderato was used in 4 etudes, adagio in 2 etudes, andante in 2 etudes, andantino in 2 etudes, allegro in 2 etudes, allegretto giocoso in 2 etudes, allegro con fuoco in 2 etudes, presto and presto molto in 1 etudes. Each of the other speed terms was applied over 1 etude as seen in the table.

Considering the etudes in general, 13 speed terms refers to playing fast and very fast and has been applied on 16 etudes. The number of speed terms expressing playing slow and medium speed is 6 and they have been applied on 12 etudes. Tempo changes occurred in only 2 etudes. These etudes are 6th and 24th etudes. According to these distributions, it can be said that almost half of the etudes are aimed to improving speed and finger agility. Therefore, students' articulation and note reading skills will also improve.

Table 11. Distribution of tones used in the etudes

\begin{tabular}{lcll}
\hline Tone of the etudes & Etude Numbers & Tone changes in the etude \\
\hline Do Major & 1 & - & - \\
\hline La Minor & 2 & - & - \\
\hline Sol Major & 3 & - & - \\
\hline Mi Minor & $4 \mathrm{a}, 4 \mathrm{~b}$ & 5 & - \\
\hline Re Minor & 6 & 41 th measure Re M/82th measure Si m \\
\hline Si Minor & 7 & - \\
\hline La Major & 8 & - \\
\hline Fa Sharp Minor & $9 \mathrm{a}, 9 \mathrm{~b}$ & - \\
\hline Mi Major & 10 & - \\
\hline Do sharp Minor & 11 & 35 th measure Sol M/72 th measure Si M \\
\hline Si Major & 12 & - \\
\hline Sol sharp Minor & 13 & - \\
\hline Fa sharp Major & 14 & 33 th measure Mi flat $\mathrm{m}$ \\
\hline Re sharp Minor & 15 & - \\
\hline Re Flat Major & 16 & - \\
\hline Si Flat Minor & 17 & - \\
\hline La Flat Major & 18 & 96 th measure Fa M/129 th measure Fa m/161 th measure Fa M/209 th measure Fa m \\
\hline Fa Minor & 19 & - \\
\hline Mi Flat Major & 20 & - \\
\hline Do Minor & 21 & - \\
\hline Si Flat Major & 22 & - \\
\hline Sol Minor & 23 & - \\
\hline Fa Major & 24 & 114 th measure Re M \\
\hline Re Minor & &
\end{tabular}

Looking at Table 11, it is seen that a total of 24 different tones are operated. 12 of them are written in major tones and 12 of them are written in minor tones. According to the table, the etudes proceed in order that the relevant minor of a major tone will be included in the next etude. In 5 etudes, tone changes were made within the etude itself.

Table 12. Summary of the results

\begin{tabular}{lc}
\hline Technical and musical subjects & Frequency \\
\hline Crescendo and decrescendo nuance & 26 \\
\hline Forte nuance & 25 \\
\hline Piano nuance & 24 \\
\hline
\end{tabular}




\begin{tabular}{ll}
\hline Mezzoforte nuance & 22 \\
\hline Interval & 22 \\
\hline Legato & 16 \\
\hline Speed and finger agility & 16 \\
\hline Arpeggio & 13 \\
\hline Staccato & 10 \\
\hline $4 / 4$ measure & 9 \\
\hline Chromatic scale & 6 \\
\hline Scale studies & 6 \\
\hline Triole Pattern & 6 \\
\hline
\end{tabular}

\section{Conclusion Discussion and Suggestions}

Etudes are mostly written in $4 / 4$ unit of measure. It has been determined that there are also etudes in $2 / 4,3 / 4,3 / 8$, 6/8, 12/8 measurement units. According to these results, 6 different measurement units were used in the etudes. In the etudes, it was determined that legato was mostly used and staccato vocalization technique was also used to a great extent. It has been studied in legato and tongued etudes. The fact that 31 different ways of legato were used in the etudes is extremely beneficial for the development of the student's flute performance. Because playing legato properly requires good breathing technique, a quality tone and a correct blowing angle.

The fact that the staccato application has been included in 9 different ways in the etudes is very useful in terms of improving the tongue technique. In addition, the tongue techniques to be applied in a etude that should be played fast according to the tempo of the etudes will also differ. In tongued etudes that require speed, it may be necessary to apply tongue techniques such as double tongued and triple tongued in etudes. Thus, it will be possible to improve on this subject by applying all tongue techniques. Cüceoğlu Önder (2012) aimed in her study to examine Carl Joachim Andersen's Op. 15, op.21, op.30, op.33, op.37, op.41, op.60/I-II, op.63/I-II flute etudes in terms of tongue techniques. Andersen's 188 flute etudes in total and the sample of the study is 62 etudes in total focusing on operating the tongue techniques. It has been concluded that in the etudes triple tongue, double tongue and single tongue are employed respectively and within Op.60, Op.63 and op.30, tongue techniques are operated extensively.

There are 17 different practice studies in which legato and tongued are used together; 2 legato, 2 legato -2 tongued, 2 legato -3 tongued. Proper application of the legato and tongued together requires to good at articulation and is a matter of etude. In this respect, it is thought that this issue is given importance in the etudes and a rich variety of examples are presented. Applications related to ornaments are included on one etude.Trill, grace note, mordan, gruppetto were operated in 10 different ways. Nevertheless, the fact that the ornamentation works are dealt with only on one etude suggests that this issue is not given much attention. Interval was run the most in studies. Also technical studies such as arpeggio, triole pattern, chromatic scale, scale studies, tonality were used in the etudes. According to these results, many technical issues such as interval, arpeggio, and chromatic scale were included in the etudes. These technical subjects can be classified according to the needs of the students and they can be studied.

Crescendo and decrescendo were used in all of the etudes. Mezzoforte, forte and piano nuances were also used mostly in etudes. Fortissimo and pianossimo nuances are given a little. In flute education, it is very difficult to be able to play according to the terms of nuances and this skill can be realized over the years. In this respect, the fact that the most basic terms of nuances are mostly included in the etudes will contribute to the development of musical thinking in the student (Önder \&Yıldız, 2017).

It was found that, allegro and its varieties were used as speed termsin most of the etudes. Also speed terms such as moderato, adagio, andante, which mean playing at slow and medium speed, were used. It can be said that most of the etudes were written in allegro tempo, so these etudes can improve speed and finger agility. In the 6th and 24th etudes, there are changes in both speed terms and metronome values. Looking at the metronome values,

it is seen that the lowest value $\downarrow=58$ and the highest value $\downarrow=144$. Considering the etudes in general, the 13 speed terms refers to playing fast and very fast and has been applied on 16 etudes. The number of speed terms expressing playing slow and medium speed is 6 and they have been applied on 12 etudes. Tempo changes 
occurred in only 2 etudes. These etudes are 6th and 24th etudes. According to these distributions, it can be said that almost half of the etudes are aimed at improving speed and finger agility. Therefore, students' articulation and note reading skills will also improve. It is thought that tempo changes in the etude have been made in order to adapt to different tempo and develop the sense of rhythm (Önder \& Yıldız, 2017).

In the etudes, it was determined that a total of 24 different tones were operated, 12 of them in major tones and 12 of them in minor tones. Etudes are arranged to run the relevant minor of a major tone. It was determined that in 5 etudes, there was a change in tone within the etude itself. Running 24 different tones in the etudes is very beneficial for the development of tonality. Fonville (1981), analyzed Andersen's etudes pedagogically in his/her study. Fonville (1981) obtained that results; Andersen's etudes are included finger agility, lip flexibility, tongue techiques, legato, tone development, ornaments, nuance, rhythm problems.

According to the results, Carl Joachim Andersen's op.15 etude book systematically covers many subjects in terms of flute education and offers a wide variety of applications. Etudes can provide to students very useful gains in flute education both in technical and musical terms. Instead of playing a etude book from the beginning to the end, the student's difficulties can be eliminated by conducting etudes on whatever subject he/she has inadequate or difficulty. With this analysis, the topics discussed in the etudes can be classified and presented in line with the needs of the student. By classifying the etudes covering similar technical and musical subjects, teachers and students can be facilitated in choosing the etude.

In flute education, the technical and musical difficulties experienced by each student are different. Some of may have difficulty in controlling breath, playing legato, some of playing staccato, arpeggio. For this reason, it may be much more beneficial to select and run etudes aimed at overcoming and correcting the technical or musical difficulties of students. In order to achieve this, it will be more beneficial to run a etude book by selecting studies according to the needs of the students instead of running it sequentially from beginning to end. By analyzing C. J. Andersen's other seven etude books, it can be determined which technical and musical subjects were included in the etudes. In addition, Andesen's other seven etude books can be analyzed comparatively. Thus, the technical and musical gains expected from the etudes can be reached high levels.

\section{References}

Andersen, C. J. (1885). Op.15 24 Grosse Etuden für Flöte Hamburg. Max Leichssenring, Larden.

Cüceoğlu, G., \& Berki, T. (2007). Flüt Eğitimine Yönelik Bir Etüd Analiz Modeli. Gazi Üniversitesi Gazi Eğitim Fakültesi Dergisi, 27(1), 227-235.

Dzapo, K. J. (1996). Carl Joachim Andersen: A Biography and Study of His Compositions for Flute and Piano (Doctoral dissertation, Northwestern University, Evanston, Illinois).

Dzapo, K. J. (2007). Joachim Andersen's Opus 15: Masterful Etudes In The Midst Of It All. Pan The Flute Magazine, March, 25-28.

Fonville, J. W. (1981). A Pedagogical Approach to the Flute Etudes of Joachim Andersen (Doctoral dissertation, University of Illinois at Urbana- Champaign, Urbana, Illinois).

Lancaster, L. K. (1994). Analyzing Flute Pedagogy: A Discussion with Selected Pedagogues (Doctoral dissertation, University of Missouri-Kansas City, Kansas City, Missouri).

Önder, C. G. (2012). Flüt Eğitiminde Kullanılan Carl Joachim Andersen Flüt Etütlerinin Dil Teknikleri Yönünden İncelenmesi. E-Journal of New World Sciences Academy, NWSA-Fine Arts, 7(2), 131-142.

Önder, C. G., \&Yıılız, E. (2017). Flüt Eğitiminde Kullanılan Ernesto Köhler Op. 33/I Etüt Kitabının Analizi. The Journal of Academic Social Science Studies, 58, 11-18. https://doi.org/10.9761/JASSS6961

Scholes, A. P. (1992). The Oxford Companion to Music. New York: Oxford University Press.

Stanley, S. (1995). The New Grove Dictionary of Music and Musicians (Vol. 18). London: Macmillan Publishers Limited.

Yıldırım, A., \& Şimşek, H. (2006). Sosyal Bilimlerde Nitel Araştırma Yöntemleri. Ankara: Seçkin Yayıncılık. 


\section{Copyrights}

Copyright for this article is retained by the author(s), with first publication rights granted to the journal.

This is an open-access article distributed under the terms and conditions of the Creative Commons Attribution license (http://creativecommons.org/licenses/by/4.0/). 